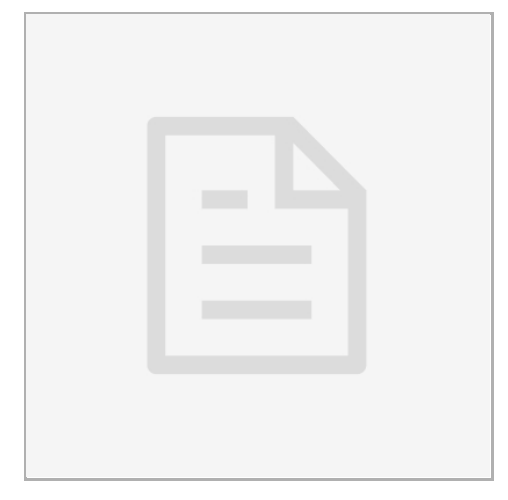

\title{
(3) An easy chromatographic method for purification of Immunoglobulin Y (IgY). V.1
}

\author{
Angel A Justiz-Vaillant ${ }^{1}$
}

${ }^{1}$ University of the West Indies St. Augustine

\section{VERSION 1}

\section{AUG 17, 2020}

\section{open ठaccess}

\section{DOI:}

dx.doi.org/10.17504/protocol s.io.bju2knye

Protocol Citation: Angel A Justiz-Vaillant 2020. An easy chromatographic method for purification of Immunoglobulin $\mathrm{Y}(\lg \mathrm{Y})$.. protocols.io

https://dx.doi.org/10.17504/p rotocols.io.bju2 knye

License: This is an open access protocol distributed under the terms of the Creative Commons Attribution License, which permits unrestricted use, distribution, and reproduction in any medium, provided the original author and source are credited

Protocol status: Working We use this protocol and it's working

Created: Aug 17, 2020

Last Modified: Aug 17, 2020

\section{PROTOCOL integer ID:}

40570

Angel A Justiz-Vaillant

University of the West Indies St. Augustine

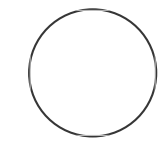


2 Snap off tab on the column outlet.

3 Wash out the ethanol with $26 \mathrm{ml}$ of de-ionized water.

4 Equilibrate column with $26 \mathrm{ml}$ of binding buffer. The recommended flow rate is $5 \mathrm{ml} / \mathrm{min}$.

5 Apply the IgY sample using a syringe fitted to Luer connector or by pumping it onto the column.

6 For better results, use a flow rate of 0.5 to $5.1 \mathrm{ml} / \mathrm{min}$ during sample application.

7 Wash with at least $51 \mathrm{ml}$ of binding buffer or no material remains in the effluent.

8 Maintain a flow rate of 5 to $11 \mathrm{ml} / \mathrm{min}$ for washing.

9 Elute with $51 \mathrm{ml}$ of elution buffer using a one-step or using a linear gradient though larger volumes are often required to break the interaction. 
10 After elution, regenerate the column by washing with $36 \mathrm{ml}$ of wash buffer.

11 Re-equilibrate the column with $26 \mathrm{ml}$ of binding buffer.

12 The column is now prepared for a new purification. 